\title{
Growth and Calcium Partitioning in Lilium 'Star Gazer' in Relation to Leaf Calcium Deficiency
}

\author{
Yao-Chien Chang ${ }^{1}$ and William B. Miller ${ }^{2}$ \\ Department of Horticulture, Cornell University, Ithaca, NY 14853-5904
}

\begin{abstract}
AdDitional INDEX wORDs. lily, plant nutrition, calcium translocation, upper leaf necrosis, leaf disorder, leaf scorch, tipburn
Abstract. Upper leaf necrosis (ULN) on Lilium 'Star Gazer' has been recently demonstrated to be a calcium (Ca) deficiency disorder. In the current studies, we confirmed this by using a Ca-free nutrient regime to reproduce ULN symptoms. The ability of a bulbous storage organ to supply calcium to a growing shoot is poorly understood. Therefore, we conducted experiments to determine Ca partitioning during early growth stages, and under suboptimal Ca levels to determine how the bulb affects the symptomatology. The results indicated that ULN is originally caused by an insufficient Ca supply from the bulb. In the most susceptible period, bulb dry matter decreased dramatically and Ca concentrations in immature folded leaves dropped to very low levels. Consequently, necrosis began to appear on the upper, young leaves. The bulb was able to supply Ca to other organs, but only to a limited extent since Ca concentration in bulbs was low $(0.04 \% \mathrm{w} / \mathrm{w})$. To confirm this result, we cultivated lilies with low-Ca or Ca-free nutrient solution and obtained bulbs with extremely low internal Ca concentrations. Upon forcing these low-Ca bulbs, we found, as expected, prominent necrosis symptoms on the lower and middle leaves. Data suggested the lower and middle leaves relied more on Ca supplied from the bulb, while upper leaves and flowers relied more on Ca uptake from the roots. Different organs have different Ca requirements, and tissue sensitivity to Ca deficiency varies according to the growth stage.
\end{abstract}

Calcium ( $\mathrm{Ca}$ ) deficiency disorders occur in many economic crops (Shear, 1975). Well-known examples include bitter pit in apples (Ferguson and Watkins, 1989), blossom-end rot in tomatoes (Adams and Ho, 1993), and tipburn in lettuce (Collier and Tibbitts, 1982). Calcium deficiency is often the consequence of insufficient $\mathrm{Ca}$ translocation to the desired organs. Previous research has focused on factors related to or affected by environment, such as growth rate (Collier and Huntington, 1983; Ho et al., 1993), transpiration (Barta and Tibbitts, 1986), solution salinity (Adams and Ho, 1992; Ho and Adams, 1994a), and root pressure (Bradfield and Guttridge, 1979; Guttridge et al., 1981; Palzkill and Tibbitts, 1977). The effects of factors within the plant were little discussed. Crops with storage organs, such as lily, may have an additional $\mathrm{Ca}$ translocation pattern since the organs obviously serve as carbohydrate and mineral nutrient reservoirs.

Upper leaf necrosis (ULN) on 'Star Gazer' lily has been recently demonstrated to be a Ca deficiency disorder (Chang, 2002). The calcium concentration in necrosed tissue was only about one-sixth that of healthy tissue, and was negatively correlated with symptom severity (Chang, 2002). Many questions remain unanswered about this disorder, such as why the disorder was never observed on lower leaves. Most plants begin to show ULN symptoms 30 to $40 \mathrm{~d}$ after planting (DAP) regardless of planting date. Thus, the timing of maximum ULN occurrence was suspected to be caused by factors within the plant itself (Chang,

Received for publication 14 Mar. 2003. Accepted for publication 8 July 2003. This paper is based on a portion of the PhD dissertation submitted by Y.C. Chang. Use of trade names does not imply endorsement of named products nor criticism of similar ones not named. We thank Timothy L. Setter and Leon V. Kochian of Cornell University for their sound advice on this project. This research was funded in part through a Specific Cooperative Agreement between the USDA-ARS Plant Protection Research Unit and the Cornell Department of Plant Pathology, Ithaca, NY (SCA \#58-1907-0-035) funded by the USDA-ARS as part of the Floriculture and Nursery Research Initiative. We gratefully acknowledge the financial and material support from the Ministry of Education, Taiwan, the Fred C. Gloeckner Foundation, the Kenneth Post-Herman Schenkel Memorial Council, and the Royal Dutch Wholesalers' Association for Flowerbulbs and Nursery Stock.

${ }^{1}$ Former graduate research assistant, held a scholarship from the Ministry of Education, Taiwan. Currently postdoctoral research associate.

${ }^{2}$ Professor and corresponding author; email wbm8@cornell.edu.
2002). We hypothesize that ULN is related to the Ca partitioning and translocation between organs within the plant.

Because it has a storage bulb, the lily is fundamentally different from other crops with Ca deficiency disorders mentioned above. The presence of the bulb might affect the development of calcium deficiency symptoms compared to other crops, and thus deserves study. The $\mathrm{Ca}$ concentration in storage organs is generally low, for example, $\approx 0.06 \%$ in potato tubers (Collier et al., 1978; Olsen et al., 1996). The distribution pattern of $\mathrm{Ca}$ in potato was very different from that of nitrogen, phosphorus, and potassium, as Ca was partitioned with a proportionately minute amount to the tubers (Bunemann and Grassia, 1973). However, the importance and extent of $\mathrm{Ca}$ remobilization from a storage organ to above ground plant biomass during development is unknown.

Reports on Ca nutrition in Lilium are limited. Data on seasonal Ca changes were obtained with field-grown Easter lilies and edible lilies (Chaplin and Roberts, 1981; Kawagishi and Miura, 1996; Roberts et al., 1964); but these reports did not provide data on Ca partitioning from the bulb during early growth stages. By constructing dry matter and Ca budgets for 'Star Gazer' lily, we may be able to answer questions mentioned above. In these studies, we conducted experiments to understand $\mathrm{Ca}$ nutrition and partitioning in Lilium 'Star Gazer' and how they are related to the symptomology of ULN.

\section{Materials and Methods}

Bulbs of Lilium 'Star Gazer' were imported from The Netherlands, and planted in $15 \mathrm{~cm}$ plastic pots with 1 soil : 2 peatmoss : 1 perlite mix (by volume). The following amendments $\left(\mathrm{kg} \cdot \mathrm{m}^{-3}\right)$ were added to the soil mix: dolomitic lime, 2.92; gypsum, 1.16; triple super phosphate, 0.58; Micromax (Scotts-Sierra Hort. Prod. Co., Marysville, $\mathrm{OH}), 0.88$; calcium nitrate, 0.28 ; potassium nitrate, 0.28 . Plants were forced in a greenhouse at Cornell University, Ithaca, N.Y., using standard cultural practices (Miller, 1992). The day/night temperature was set to $17 / 17^{\circ} \mathrm{C}$. Plants were fertigated with 15N-2.2P-12.5K fertilizer(Excel 15-5-15, Scotts-SierraHort. Prod. Co., Marysville, Ohio) at the concentration of $200 \mathrm{mg} \cdot \mathrm{L}^{-1}$ $\mathrm{N}$ during the experiment. Calcium concentration in the fertilizer 
solution was $67 \mathrm{mg} \cdot \mathrm{L}^{-1}$. An unfolded leaf was defined as when $>75 \%$ of its leaf surface was not in contact with other leaves. The incidence of ULN occurrence was defined as the percentage of plants that had any level of symptom expression. To further refine differences between necrosed plants, an index from 0 to 5 , based on necrosed leaf area, was developed to describe the severity of necrosis on individual leaves: $0=$ a leaf with no visible necrosis symptoms, $1=$ a leaf with chlorotic spots, $2=$ a leaf with curled leaf margin, $3=$ a leaf with marginal necrosis, $4=$ a leaf with dead leaf tip, $5=$ when $>50 \%$ of the leaf area was necrotic.

When the severity level was between two index categories, the average was used. The severities of the individual single leaves were then summed to give whole plant severity. When whole plant severity was $<5$, the symptoms were very light, and would typically not be visible to the casual observer. Unless otherwise noted, all results in this study are on a dry weight basis.

Sequential HarVeST EXPERIMENT. This experiment was conducted to characterize calcium pool sizes during normal growth. Ninety-five 16 to $18 \mathrm{~cm}$ circumference bulbs $(65.2 \pm 0.4 \mathrm{~g}$ fresh weight; a size that is routinely susceptible to the disorder) were planted on $15 \mathrm{Feb}$. Six randomly selected plants were harvested at 10-d intervals from 0 to 70 DAP. Harvested plants were washed with reverse-osmosis (RO) water and dissected into scales, basal plate, basal roots, stem roots, stem, flowers, L13 (the $13^{\text {th }}$ leaf from the bottom), L1F (the larger leaf associated with the first flower bud), unfolded leaves, and folded leaves. Those organs were then rinsed twice in distilled water, oven-dried to a constant weight at 70 ${ }^{\circ} \mathrm{C}$, and the $\mathrm{Ca}$ concentration was determined by inductively coupled plasma spectrometry (ICP) at wavelength of $317.9 \mathrm{~nm}$. Data of L13, L1F, unfolded leaves, and folded leaves were then summed to indicate data for all leaves. Data of scales and basal plate were combined to provide bulb data. Data on calcium concentration (on the basis of plant or organ dry weight), and Ca content per organ (the product of $\mathrm{Ca}$ concentration and organ dry weight) were calculated.

Nutrient Ca Level (SAND Culture) EXPERIMENT. This experiment was conducted to clarify the role of calcium availability during growth on the development of ULN. Q-ROK sand (U.S. Silica, Berkeley Springs, W.Va.) was washed with RO water 10 times before use. Eighty 14 - to 16 -cm bulbs $(49.3 \pm 0.4 \mathrm{~g}$ fresh weight) were planted in pots containing sand on 11 Apr. Smaller bulbs were used in this experiment as they are less susceptible to ULN. After planting, bulbs were divided into 5 groups to receive different $\mathrm{Ca}$ nutrient solutions. Another five bulbs were harvested to determine the initial bulb Ca content. Plants were fertigated with complete $(4.0 \mathrm{~mm} \mathrm{Ca})$, $5 \%$ Ca strength $(0.2 \mathrm{~mm})$, or Ca-free $(0.0 \mathrm{~mm})$ modified Johnson solutions (Johnson et al., 1957) depending on the treatments. The composition of the complete nutrient solution was $\left(\mathrm{mmol} \cdot \mathrm{L}^{-1}\right) \mathrm{N}, 16 ; \mathrm{P}, 2 ; \mathrm{K}, 6$; Ca, 4; S, 1; Mg, 1 and $\left(\mu \mathrm{mol} \cdot \mathrm{L}^{-1}\right) \mathrm{Cl}, 50 ; \mathrm{B}, 25 ; \mathrm{Fe}, 10 ; \mathrm{Mn}, 2$; $\mathrm{Zn}, 2$; $\mathrm{Cu}, 0.5 ; \mathrm{Mo}, 0.5$; Ni, 0.1. $\mathrm{NaNO}_{3}$ was the substitute for $\mathrm{Ca}\left(\mathrm{NO}_{3}\right)_{2} \bullet 4 \mathrm{H}_{2} \mathrm{O}$ in the Ca-free and $0.2 \mathrm{~mm} \mathrm{Ca}$ treatments to maintain the ion balance of nutrient solution. There were five treatments (different Ca regimes) and 16 replications of each treatment in a completely randomized experimental design. Treatments were as follows.

1) $4.0 \mathrm{~mm} \mathrm{Ca}$ nutrient solution (control).

2) $0.2 \mathrm{~mm}$ Ca solution.

3) $0.0 \mathrm{~mm}$ Ca solution.

4) $4.0 \mathrm{~mm}$ Ca solution initially, then switched to $0.2 \mathrm{~mm} \mathrm{Ca} 41 \mathrm{DAP}$. 5) $4.0 \mathrm{~mm}$ Ca solution initially, then switched to $0.0 \mathrm{~mm} \mathrm{Ca} 41 \mathrm{DAP}$.

DAP 41 was the day ULN first occurred. Before nutrient programs were switched, pots were leached 10 times with RO water. At 88 DAP, five plants were randomly selected and harvested from the 4.0,0.2, and $0.0 \mathrm{~mm}$ treatments. Harvested plants were washed with $\mathrm{RO}$ water, dissected into roots (including both stem roots and basal roots), bulb (including scales and basal plate), leaves, stem, and flowers. Samples were rinsed in distilled water twice, oven-dried to a constant weight at $70{ }^{\circ} \mathrm{C}$, and Ca concentration determined by ICP. Plant height was taken 84 DAP. Sands at planting and after

Fig. 1. Changes in calcium concentration, calcium content, and dry matter (top, middle, and bottom panels, respectively) in Lilium 'Star Gazer' in the first 70 days after planting. Anthesis would have occurred $\approx 90 \mathrm{~d}$ after planting. Each point represents mean \pm SE of six replications.
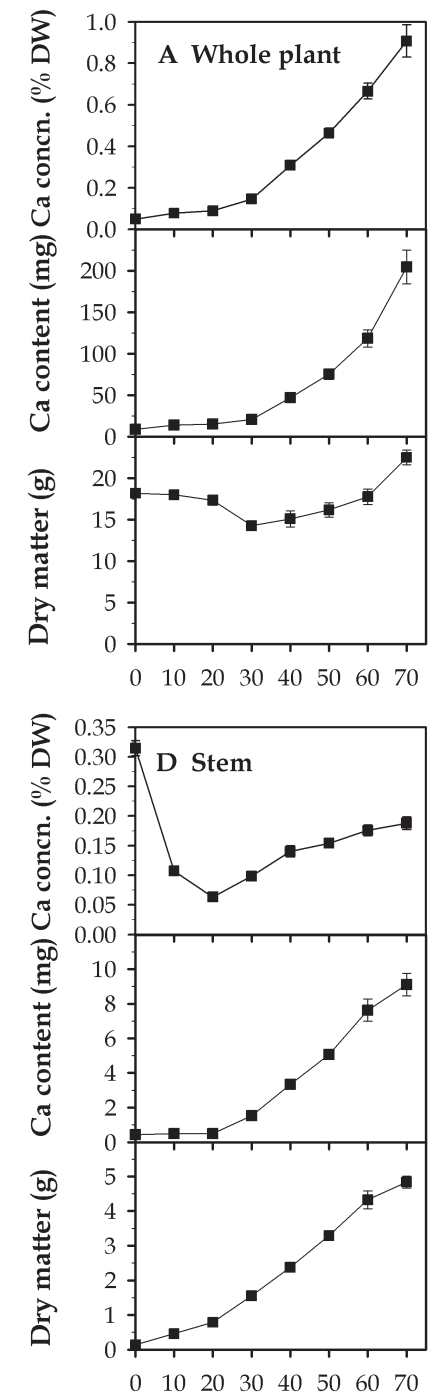

Days after planting
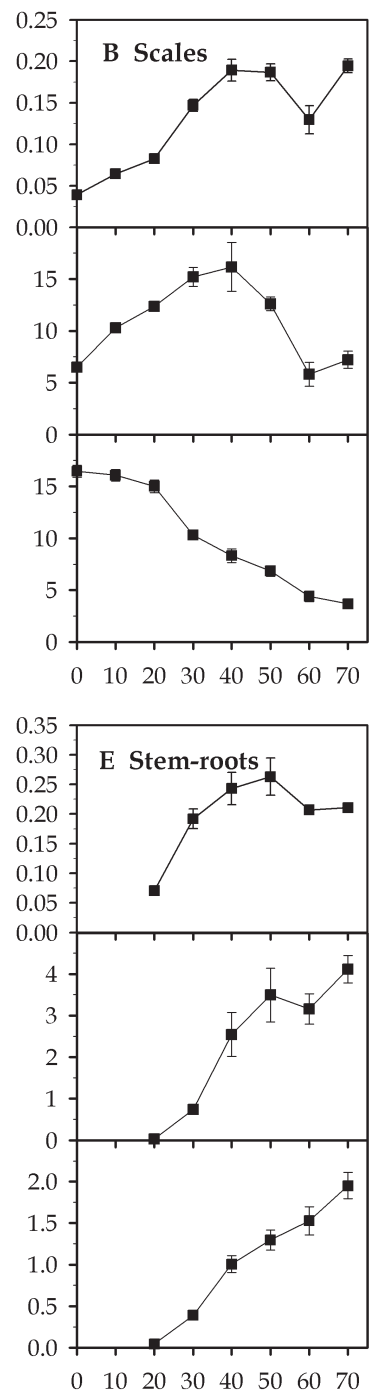

Days after planting
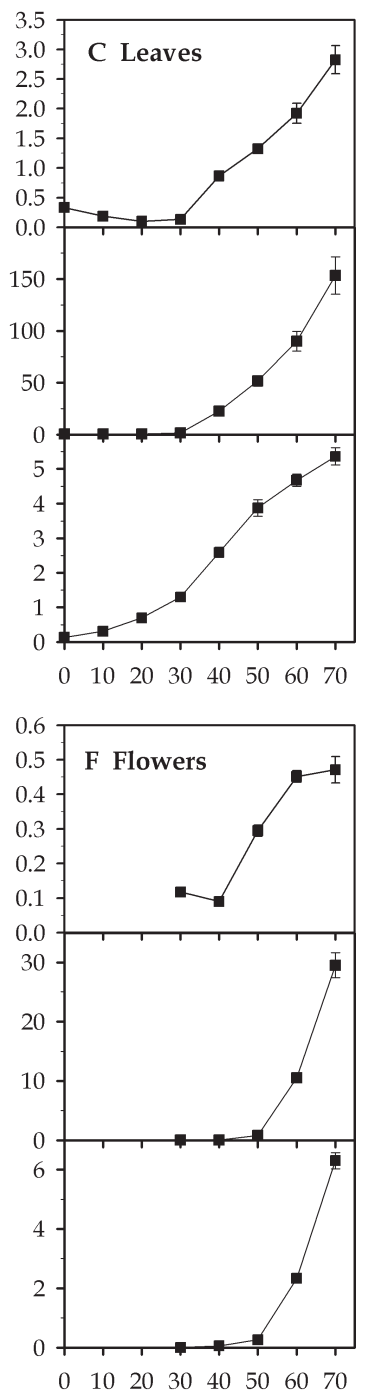

Days after planting 
harvesting were analyzed and nutrition solutions were randomly checked to ensure there was no Ca contamination.

LOW-Ca BUlb EXPERIMENT. This experiment was conducted to assess the importance of endogenous bulb calcium level on subsequent development of ULN. Plants in the sand culture experiment continued to receive 4.0,0.2, or $0.0 \mathrm{~mm}$ Ca nutrient solution until bulbs were harvested on 25 Nov. Bulbs harvested from 4.0 $\mathrm{mm} \mathrm{Ca}$ treatments were categorized as normal-Ca bulbs in this experiment, and bulbs from other treatments were categorized as low-Ca bulbs. Four normal-Ca bulbs and 16 low-Ca bulbs were randomly selected for $\mathrm{Ca}$ analysis. The rest of the bulbs ( 7 normal-Ca bulbs and 17 low-Ca bulbs) were placed in moist sand and stored at $3{ }^{\circ} \mathrm{C}$. On 7 Mar., these bulbs were planted and grown as described above. Calcium concentration in the fertilizer solution was $67 \mathrm{mg} \cdot \mathrm{L}^{-1}$. A completely randomized experimental design was used in this experiment.

\section{Results}

Plant growth and ULN. It took $10 \mathrm{~d}$ for $50 \%$ of the shoots to emerge. In the first $30 \mathrm{~d}$ after bulbs were planted, total plant dry matter decreased, but then slowly increased over the next $40 \mathrm{~d}$ (Fig. 1A; Table 1). The reduction of dry matter was mainly due to depletion of the bulb scales, which, after a 20-d lag, were continually depleted over the 70-d experiment (Fig. 1B; Table 1). Dry matter of all other organs (Fig. 1C-F; Table 1), except basal plate (data not shown) and basal roots (Table 1), increased over time. The most dramatic reduction in bulb scale dry matter was from $20 \mathrm{DAP}$ to $30 \mathrm{DAP}$ (Fig. 1B). In this period, the lily plant was translocating reserves from the bulb scales to other organs in order to rapidly build up shoot biomass. The slope of the leaf growth curve increased sharply after 30 DAP (Fig. 1C), and the stem after 20 DAP (Fig. 1D). Stem roots began to develop about $10 \mathrm{~d}$ after planting. Dry matter of stem roots was only $0.05 \mathrm{~g}$ on 20 DAP, and $0.4 \mathrm{~g}$ on 30 DAP (Table 1; Fig. 1E). Stem roots developed rapidly from 30 to $40 \mathrm{DAP}$, and increased with time (Fig. 1E). The dry matter change of basal roots was opposite that of stem roots. Only a few newly grown branched roots were found on basal roots and basal roots decayed with time (Table 1).
Flower buds were visible at $\approx 50$ DAP and rapid flower growth occurred after that (Fig. 1F). Similar to results in our previous study (Chang, 2002), many plants began to show ULN symptoms within the 30 to 40 DAP period. This was the period that the lily shoot grew rapidly (Table 1; Fig. $1 \mathrm{C}$ and D), while bulb dry matter was decreasing dramatically (Fig. 1B; Table 1). In this period, leaf L13 (the 13t leaf from the bottom, a representative of the lower leaves), was almost mature (Fig. 2A); while leaf L1F (the larger leaf associated with the first flower bud, an upper leaf representative), was still young, weighing less than one fiftieth of its final weight (Fig. 2B).

Calcium concentration Changes. Whole plant Ca concentration increased only slowly in the first month, but increased rapidly thereafter (Fig. 1A). In general, Ca concentration of all organs increased with time (Fig. 1B-F). The only exception was basal roots, where Ca remained at a level of $0.3 \%$ to $0.4 \% \mathrm{w} / \mathrm{w}$ (data not shown). There were exceptions, however, in the first $30 \mathrm{~d}$, the leaf Ca concentration decreased gradually (Fig. 1C). This dilution effect was more apparent for the young, folded leaves: a 6-fold decrease in $30 \mathrm{~d}$ (Fig. 2D), and in stems, a 5-fold decrease in the first $20 \mathrm{~d}$ (Fig. 1D). Ca concentration in bulb scales was very low compared to the other organs. When planted (0 DAP), bulb Ca concentration was only $0.04 \%$. Although bulb Ca concentration increased with time, it only reached $0.2 \%$ (Fig. 1B).

Leaves had the highest $\mathrm{Ca}$ concentration. Ca concentration increased from $0.3 \%$ when planted to $2.8 \%$ on 70 DAP (Fig. 1C). Stems, flowers, and stem roots had medium levels of Ca concentration, ranging from $0.1 \%$ to $0.5 \%$ (Fig. 1D-F). Interestingly, the basal plate, a critical organ in the pathway of nutrient movement from the scales to the shoot, had a higher Ca concentration than bulb scales at all times, nearly 2-fold greater in the first $20 \mathrm{~d}$ (data not shown). Given 40 DAP as an example, bulb scales, leaves, stem, stem roots, and flowers had a Ca concentration of $0.19 \%$, $0.87 \%, 0.14 \%, 0.24 \%$, and $0.09 \%$, respectively (Fig. 1B-F).

Calcium content changes. Calcium content (milligrams per plant or organ) of the whole plant increased from $9 \mathrm{mg}$ at planting to $204 \mathrm{mg}$ at 70 DAP (Table 1). However, there was a lag in the first month, during which whole plant Ca content did not increase greatly (Fig. 1A). After their respective lag phases,

Table 1. Changes in dry weight and calcium content on Lilium 'Star Gazer' grown under regular calcium regime in the first $70 \mathrm{~d}$ of growth. Values in parentheses show the percentage of each organ to the whole plant; $n=6$.

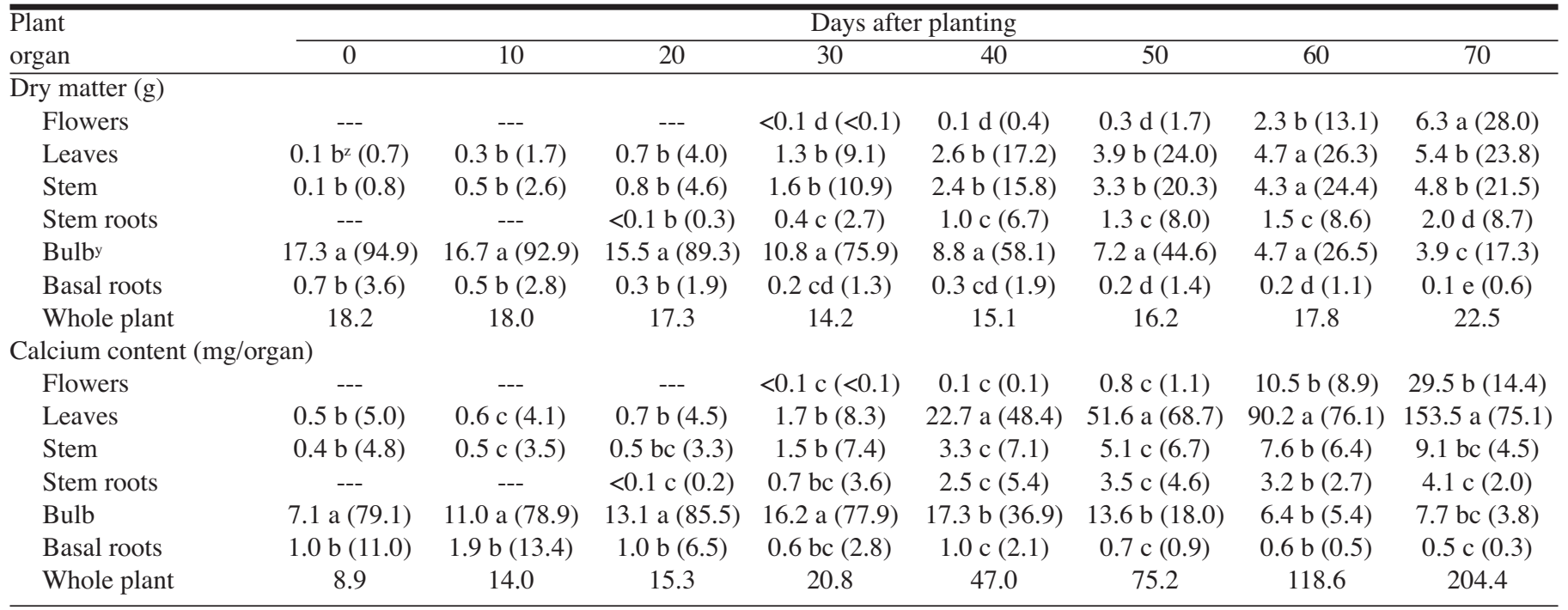

zMeans followed by a different letter in columns are significantly different at $P \leq 0.05$ by Duncan's multiple range test.

yBulb data were combined from scales and the basal plate. 

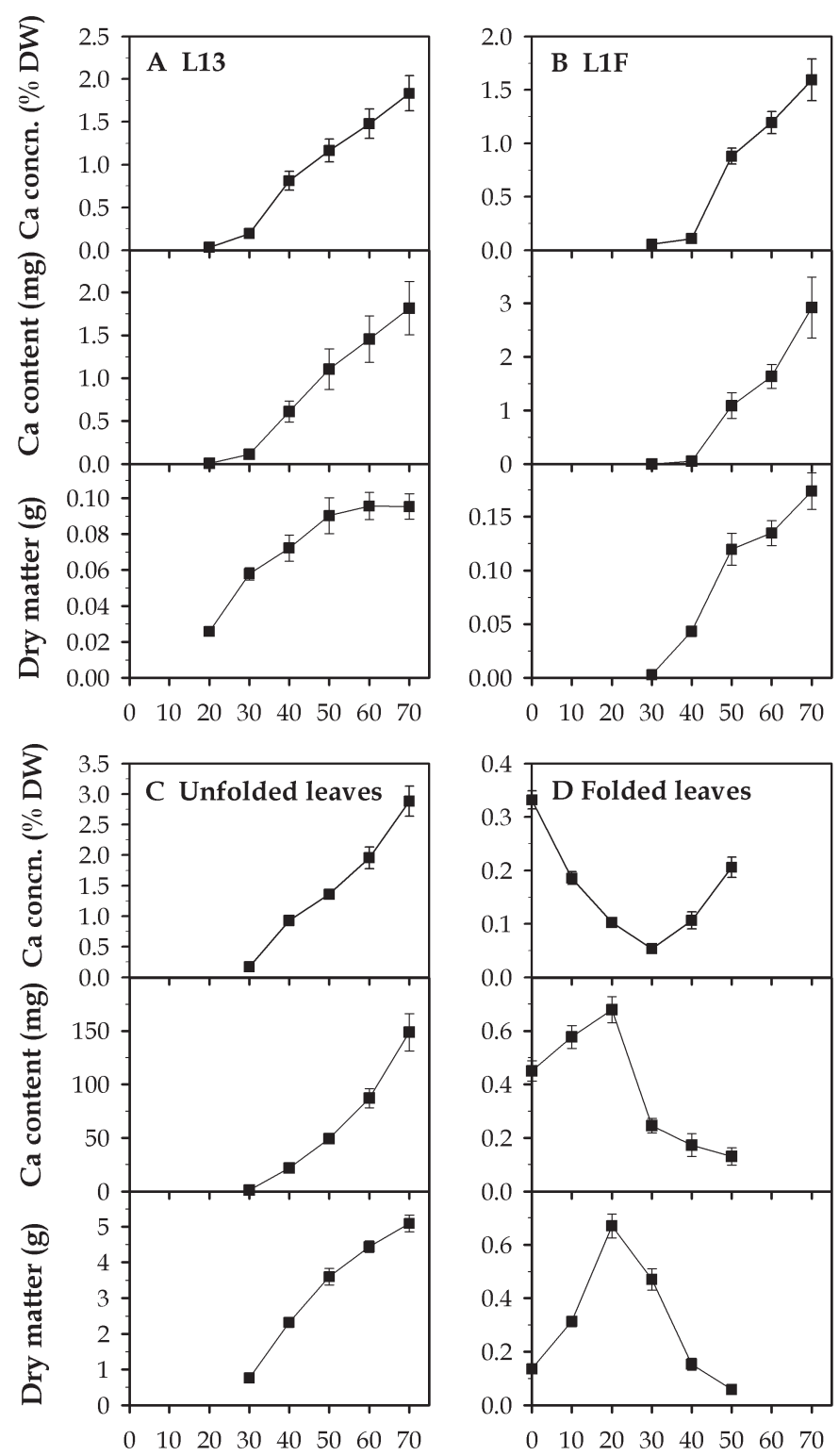

Days after planting

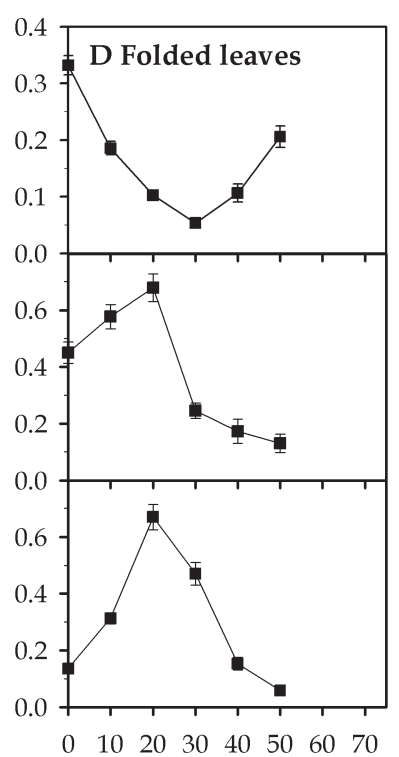

Days after planting

Fig. 2. Changes in calcium concentration, calcium content, and dry matter in different leaf fractions on Lilium 'Star Gazer' in the first 70 d after planting: (A) the 13 th leaf from the bottom (L13); (B) the larger leaf associated with the first flower bud (L1F); (C) unfolded leaves; (D) folded leaves. Each point represents mean $\pm \mathrm{SE}$ of six replications.

the Ca content of leaves, stem, stem roots, and flowers steadily increased with time (Table 1; Fig. 1C-F). Leaf Ca content increased dramatically after 30 DAP. In the first month of growth, leaf dry matter increased, but Ca concentration decreased, so $\mathrm{Ca}$ content did not change much and was very low (Fig. 1C; Table 1). A similar effect was seen in stem $\mathrm{Ca}$ content. The final 40 to $50 \mathrm{~d}$ were periods of large $\mathrm{Ca}$ accumulation in leaves and stems (Fig. 1C and D). Calcium content of flowers increased mainly after 50 DAP (Fig. 1F), once rapid bud growth began.

Unlike leaves, stem, flowers and stem roots, $\mathrm{Ca}$ content of scales and basal roots increased transiently after planting, but then decreased some weeks later (Fig. 1B; Table 1). Although bulb scales lost about half their dry matter in the first 40 DAP, bulb Ca content actually doubled in the same time (Table 1; Fig. 1B).

Table 2. Effect of nutrient solution calcium concentration on upper leaf necrosis on Lilium 'Star Gazer'. Bulbs (14 to $16 \mathrm{~cm}$ ) were planted in pure play sand and irrigated with nutrient solution as indicated; $n=16$.

\begin{tabular}{|c|c|c|c|c|c|}
\hline \multirow{2}{*}{$\begin{array}{l}\text { Calcium } \\
\text { level } \\
(\mathrm{mm}) \\
\end{array}$} & \multicolumn{2}{|c|}{ Necrosis } & \multicolumn{2}{|c|}{ Plant ht $(\mathrm{cm})$} & \multirow{2}{*}{$\begin{array}{c}\text { Plants with } \\
\text { aborted } \\
\text { flower } \\
\text { buds (\%) }\end{array}$} \\
\hline & Incidence (\%) & Severity & to $1 \mathrm{st}$ bud & to top & \\
\hline 4.0 (control) & 12.5 & $0.1 \mathrm{c}^{\mathrm{z}}$ & $31.6 \mathrm{a}$ & $52.6 \mathrm{a}$ & 0 \\
\hline 0.2 & $75.0^{* * * *}$ & $4.1 \mathrm{~b}$ & $30.9 \mathrm{a}$ & $50.2 \mathrm{a}$ & $0^{\mathrm{Ns}}$ \\
\hline 0.0 & $100.0^{* * *}$ & $40.9 \mathrm{a}$ & $28.8 \mathrm{~b}$ & $35.0 \mathrm{~b}$ & $100^{* * * *}$ \\
\hline 4.0 to $0.2 y$ & $6.3^{\mathrm{Ns}}$ & $<0.1 \mathrm{c}$ & $30.5 \mathrm{ab}$ & $49.4 \mathrm{a}$ & $0^{\text {ss }}$ \\
\hline 4.0 to $0.0 y$ & $31.3^{\mathrm{Ns}}$ & $1.1 \mathrm{c}$ & $31.4 \mathrm{a}$ & $52.0 \mathrm{a}$ & $0^{\text {ss }}$ \\
\hline
\end{tabular}

${ }^{2}$ Means in the column followed by a different letter in columns significantly different at $P \leq 0.05$ by Duncan's multiple range test. yFertigation program switched $41 \mathrm{~d}$ after planting.

Ns,****Nonsignificant or significant at $P \leq 0.001$ compared to control by chi-square test.

After 40 DAP, bulb Ca content dropped dramatically, since more than half the scale dry weight had been lost (Fig. 1B; Table 1). Calcium content of the basal plate showed a similar trend as bulb scales (data not shown). Calcium content of basal roots increased in the first $10 \mathrm{~d}$, then decreased thereafter. This was because they decayed with time and $\mathrm{Ca}$ concentration was almost constant (data not shown). Leaf L1F was susceptible to ULN within the 30 to 40 DAP period (Chang, 2002). At this period, Ca content of leaf L1F was very low, but thereafter increased steadily until 70 DAP, when the experiment ended (Fig. 2B).

EFFECT OF NUTRIENT SOLUTION CALCIUM LEVEL ON ULN. Shoots emerged 10 DAP, and ULN began to appear at 41 DAP, just as leaf U4 (the $4^{\text {th }}$ leaf beneath the flower buds) unfolded. Plants in the calcium switch treatments began to show ULN 44 DAP, $3 \mathrm{~d}$ after the control (full calcium) treatment. The control group had low ULN incidence and severity ( $12.5 \%$ and 0.1 , respectively). As the concentration of $\mathrm{Ca}$ in the nutrient solution decreased, ULN significantly increased in both incidence and severity. Seventy-five percent of plants in the $0.2 \mathrm{~mm} \mathrm{Ca}$ treatment were necrosed, with an average severity of 4.1 . With $\mathrm{Ca}$-free $(0 \mathrm{~mm} \mathrm{Ca})$ nutrient solution, all the plants were necrosed with an extremely high severity of 40.9 (Table 2 ). For plants receiving no $\mathrm{Ca}$, the smaller leaves associated with flower buds had more severe ULN symptoms than the larger leaves. This was the opposite of all our previous experiments which were conducted in the presence of normal Ca fertilization (Chang, 2002). The ULN incidence and severity in the 4.0 to $0.2 \mathrm{~mm}$ Ca treatment were very similar to those of control. In the 4.0 to $0.0 \mathrm{~mm} \mathrm{Ca}$ treatment, both ULN incidence and severity were increased compared to the control, although the changes were not statistically significant.

Sand-grown plants irrigated with Ca-free solution had very severe ULN symptoms; flower buds were initiated, but failed to develop. All buds in the Ca-free treatment aborted, and the tops of all plants were severely necrosed, leading to reduced plant height. Flower buds in all other treatments developed and flowered normally and they reached anthesis in a similar time frame (Table 2). However, there were two plants in the $0.2 \mathrm{~mm}$ treatment and two plants in the 4.0 to $0.0 \mathrm{~mm} \mathrm{Ca}$ treatment that had slightly distorted flowers and necrosed tepal margins. When harvested 88 DAP, plants in $0.0 \mathrm{~mm}$ Ca treatment had poor stem roots, but had bigger bulbs (Table 3 ). This is probably because of the severe lack of growth due to aborting flowers that took place earlier, and bulb resources were not used to support their growth.

At planting, the average Ca concentration in bulbs was $0.05 \%$. 
Table 3. Effect of nutrient solution calcium concentration on dry matter and calcium level in different organs of Lilium 'Star Gazer', after 88 $\mathrm{d}$ exposure to the indicated calcium concentrations. At planting, bulb dry matter, bulb calcium concentration, and bulb calcium content were $12.9 \mathrm{~g}, 0.05 \%$, and $6.0 \mathrm{mg}$, respectively; $\mathrm{n}=5$.

\begin{tabular}{|c|c|c|c|c|c|c|}
\hline $\begin{array}{l}\text { Calcium } \\
\text { level } \\
(\mathrm{mm})\end{array}$ & Roots $^{2}$ & Bulby & Leaves & Stem & Flowers & Total \\
\hline \multicolumn{7}{|c|}{ Dry matter $(\mathrm{g})$} \\
\hline 4 (control) & $5.5 \mathrm{a}^{\mathrm{x}}$ & $5.5 \mathrm{~b}$ & $5.6 \mathrm{a}$ & $3.9 \mathrm{a}$ & $7.3 \mathrm{a}$ & $27.7 \mathrm{a}$ \\
\hline 0.2 & $5.8 \mathrm{a}$ & $5.9 \mathrm{~b}$ & $5.4 \mathrm{a}$ & $3.5 \mathrm{a}$ & $6.5 \mathrm{a}$ & $27.3 \mathrm{a}$ \\
\hline 0.0 & $3.6 \mathrm{~b}$ & $10.8 \mathrm{a}$ & $4.4 \mathrm{~b}$ & $2.9 \mathrm{~b}$ & $---w$ & $21.7 \mathrm{~b}$ \\
\hline \multicolumn{7}{|c|}{ Calcium concentration (\% dry weight) } \\
\hline 4 (control) & $0.42 \mathrm{a}$ & $0.06 \mathrm{a}$ & $3.41 \mathrm{a}$ & $0.21 \mathrm{a}$ & $0.23 \mathrm{a}$ & \\
\hline 0.2 & $0.04 \mathrm{~b}$ & $0.02 \mathrm{~b}$ & $0.20 \mathrm{~b}$ & $0.06 \mathrm{~b}$ & $0.03 \mathrm{~b}$ & \\
\hline 0.0 & $0.04 \mathrm{~b}$ & $0.01 \mathrm{~b}$ & $0.04 \mathrm{~b}$ & $0.02 \mathrm{c}$ & --- & \\
\hline \multicolumn{7}{|c|}{ Calcium content (mg) } \\
\hline 4 (control) & $21.6 \mathrm{a}$ & $3.2 \mathrm{a}$ & $191.9 \mathrm{a}$ & $8.1 \mathrm{a}$ & $16.8 \mathrm{a}$ & $241.5 \mathrm{a}$ \\
\hline 0.2 & $2.4 \mathrm{~b}$ & $1.2 \mathrm{~b}$ & $11.1 \mathrm{~b}$ & $2.0 \mathrm{~b}$ & $1.6 \mathrm{~b}$ & $18.3 \mathrm{~b}$ \\
\hline 0.0 & $1.3 \mathrm{~b}$ & $1.3 \mathrm{~b}$ & $1.6 \mathrm{~b}$ & $0.7 \mathrm{c}$ & --- & $5.0 \mathrm{~b}$ \\
\hline
\end{tabular}

${ }^{2}$ Roots data were combined from stem roots and basal roots.

yBulb data were combined from scales and basal plate.

${ }^{x}$ Means in the column followed by a different letter are significantly different at $P \leq 0.05$ by Duncan's multiple range test.

wFlower buds were aborted.

Eighty-eight days after planting, those plants receiving $4 \mathrm{~mm} \mathrm{Ca}$ had much higher Ca concentration in all organs. The Ca concentration in roots, bulb, leaves, stem, and flowers were $0.42 \%, 0.06 \%$, $3.41 \%, 0.21 \%$, and $0.23 \%$, respectively (Table 3 ). These data were consistent with the data at the termination of the sequential harvest experiment (Table 1), except that bulb Ca concentration in this experiment was lower. Plants grown with $0.2 \mathrm{~mm} \mathrm{Ca}$ had much less $\mathrm{Ca}$ concentration in all organs compared to plants in the control group. Among all organs, leaves had the highest $\mathrm{Ca}$ concentration $(0.2 \%)$, and bulbs the lowest, at $0.02 \%$. Organs of plants grown with $\mathrm{Ca}$-free nutrient solution had extremely low $\mathrm{Ca}$ concentration. Ca concentration was as low as $0.04 \%$ in leaves, and only $0.01 \%$ in the bulb (Table 3).

At planting, the average Ca content of the bulbs was $6.0 \mathrm{mg}$. After $88 \mathrm{~d}$, plants receiving the $4 \mathrm{~mm}$ Ca had a total of $242 \mathrm{mg}$ $\mathrm{Ca}$ in the whole plant. Among organs, leaves had the highest $\mathrm{Ca}$ content, $192 \mathrm{mg}$, which was $79 \%$ of the whole plant Ca content. The leaf Ca partition was similar to that in the sequential harvest experiment. Whole plants grown with $0.2 \mathrm{~mm} \mathrm{Ca}$ treatment had only $18.3 \mathrm{mg}$ of Ca, about one-thirteenth that of the controls. Among all organs, leaves still had the highest $\mathrm{Ca}$ content, 11.1 $\mathrm{mg}$ or $61 \%$ of the total $\mathrm{Ca}$. The $\mathrm{Ca}$ content in plants receiving Ca-free solution was only $5.0 \mathrm{mg}$, even less than the amount ( 6.0 $\mathrm{mg}$ ) initially present in the bulb at planting. Although leaves had the highest $\mathrm{Ca}$ content of $1.6 \mathrm{mg}$, it was just $32 \%$ of the total $\mathrm{Ca}$ (Table 3).

The necrosis symptoms found on the Ca-free treated plants were identical to the symptoms found in all our other experiments using 16- to $18-\mathrm{cm}$ bulbs. The symptoms included depressed regions on lower leaf surface, water-soaked tissue, purplish leaves, marginal leaf necrosis, leaf curling, leaf distortion, and leaf tip death. But, it was more severe in degree, so shoot tip death and flower abortion also occurred. It was notable that even when no Ca was supplied by the soil and nutrient solution, necrosis symptoms were still found only on the upper leaves.

EFFeCt of bULb CALCIUM CONCENTRATION ON ULN. After data
Table 4. Effect of bulb calcium $(\mathrm{Ca})$ concentration at planting on the stage that Lilium 'Star Gazer' began to show upper leaf necrosis (ULN) symptoms.

\begin{tabular}{ccccc}
\hline & $\begin{array}{c}\text { Bulb } \\
\text { fresh wt } \\
\text { when }\end{array}$ & \multicolumn{3}{c}{$\begin{array}{c}\text { When ULN symptoms } \\
\text { began to show }\end{array}$} \\
\cline { 2 - 5 } Replication & planted (g) & DAP & $\begin{array}{c}\text { Leaf } \\
\text { location }\end{array}$ & $\begin{array}{c}\text { Plant } \\
\text { ht }(\mathrm{cm})\end{array}$ \\
\hline Normal Ca bulbs & (Ca concentration & $0.026 \%$ & dry & weight) \\
Bulb 1 & 121.6 & 41 & L40y & 24.2 \\
Bulb 2 & 115.2 & 41 & L41 & 27.0 \\
Bulb 3 & 128.9 & 41 & L41 & 28.0 \\
Bulb 4 & 107.4 & 46 & L42 & 28.2 \\
Bulb 5 & 116.2 & 41 & L44 & 31.0 \\
Bulb 6 & 109.8 & 48 & L48 & 33.1 \\
Average & 116.5 & 43 a & L43 a & 28.6 a \\
Low Ca bulbs & Ca concentration $0.009 \%$ dry weight) & \\
Bulb 1 & 72.2 & 30 & L1 & 0.8 \\
Bulb 2 & 99.4 & 26 & L12 & 1.8 \\
Bulb 3 & 83.3 & 24 & L6 & 2.3 \\
Bulb 4 & 71.9 & 22 & L8 & 2.6 \\
Bulb 5 & 101.1 & 24 & L1 & 2.8 \\
Bulb 6 & 42.3 & 17 & L7 & 4.2 \\
Bulb 7 & 66.7 & 21 & L3 & 4.5 \\
Bulb 8 & 78.8 & 16 & L9 & 5.2 \\
Bulb 9 & 40.3 & 23 & L8 & 6.1 \\
Bulb 10 & 46.6 & 24 & L9 & 7.0 \\
Bulb 11 & 77.2 & 30 & L13 & 11.7 \\
Bulb 12 & 50.8 & 28 & L13 & 17.2 \\
Bulb 13 & 66.9 & 34 & L24 & 19.4 \\
Average & 69.0 & 25 b & L9 b & $6.6 \mathrm{~b}$ \\
\hline
\end{tabular}

${ }^{2} \mathrm{DAP}=$ days after planting.

y $40=$ the 40th leaf form the bottom

xMeans followed by a different letter are significantly different at $P \leq 0.05$ by Duncan's multiple range test.

were collected in the calcium nutrition experiment (above), plant growth was continued and $\mathrm{Ca}$ nutrient regimes maintained until plants senesced in November. The average Ca concentration in bulbs from the $4.0 \mathrm{mmCa}$ treatment (normal-Cabulbs) was $0.026 \%$, and only $0.009 \%$ in low-Ca bulbs (those from the $0.2 \mathrm{~mm} \mathrm{Ca}$ and Ca-free treatments). After receiving a normal vernalization, bulbs were replanted in March and grown in a soil mix with a standard fertilizer regime, including calcium.

In the control group (normal-Ca bulbs), six of the seven plants had necrosed leaves. They began to show ULN symptoms between 41 and 48 DAP when average plant height was $28.6 \mathrm{~cm}$ (Table 4). Necrosis only occurred on the upper leaves, the average location first showing symptoms being the $43^{\text {rd }}$ leaf. When planted, the lowCa bulbs were smaller, and the fresh weight of individual bulbs in the population was extremely variable (Table 4). Consequently, plants grown from these bulbs were also quite variable in size, but they uniformly exhibited very severe Ca deficiency symptoms. Of the 17 bulbs planted, 3 of them were too weak to emerge and one was stunted and died at the height of $9.7 \mathrm{~cm}$. No data could be collected from these four plants. The other 13 expressed different degrees of necrosis symptoms. Besides symptoms being much more severe, the major difference compared to the control group was that symptoms occurred much earlier and also on the lower and middle leaves (Table 4; Fig. 3).

Plants grown from the low-Ca bulbs began to show necrosis symptoms from 17 to $34 \mathrm{DAP}$, when plants were between 0.8 and $19.4 \mathrm{~cm}$ tall. The average leaf location that necrosis symptoms 


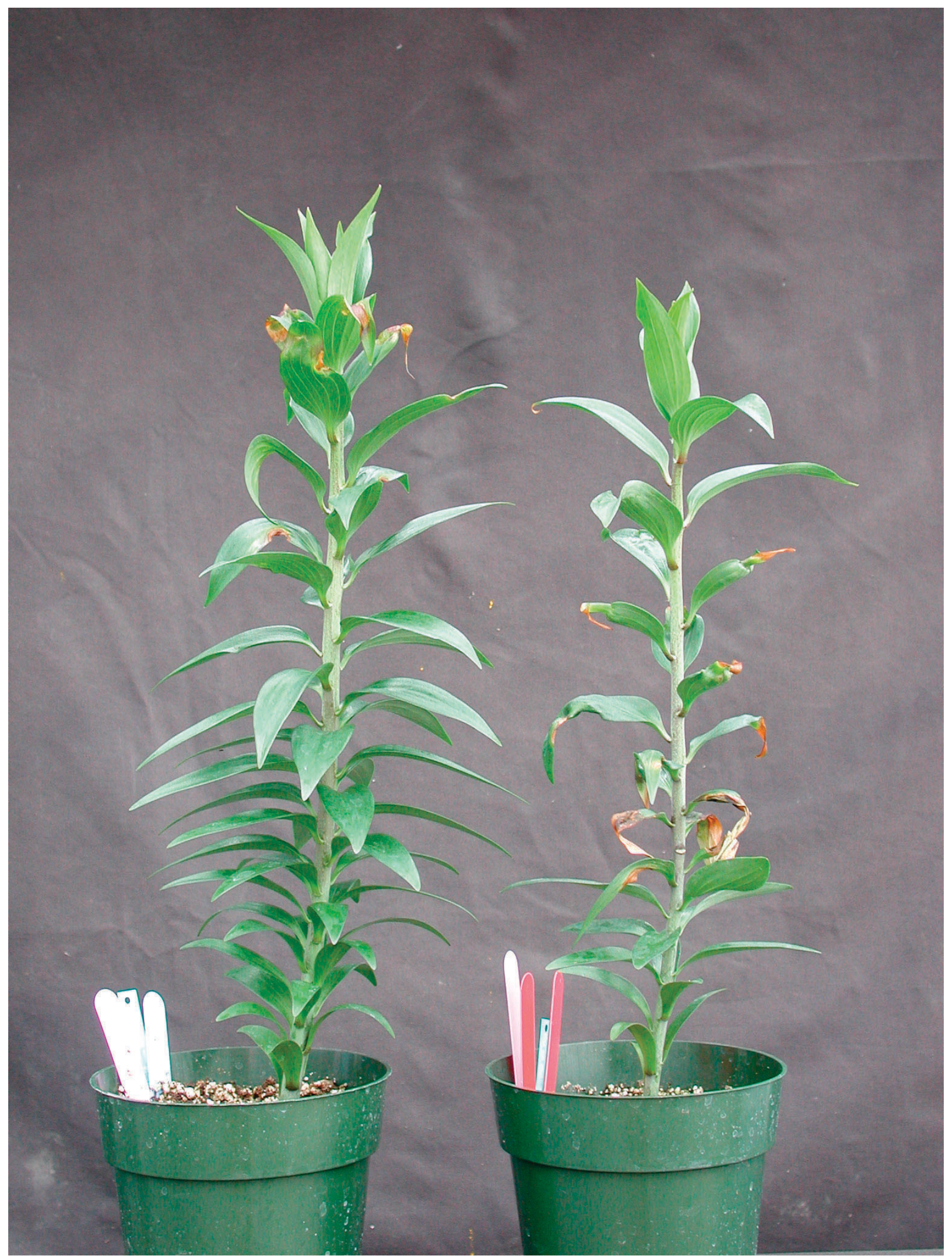

Fig. 3. Effect of endogenous bulb calcium level on upper leaf necrosis on Lilium 'Star Gazer'. Plant on the left was grown from a normal-calcium bulb; necrosis symptoms appeared only on the upper leaves. Plant on the right was grown from a low-calcium bulb; necrosis symptoms appeared on the middle and lower leaves. 
began to exhibit in the low-Ca group was L9, while it was L43 in the normal-Ca group. In the low-Ca group, two plants even showed symptoms from the $1^{\text {st }}$ leaf (L1) and several began on the first 10 leaves (Table 4). The symptoms included depressed lower leaf surface, water-soaked tissue, purplish leaves, leaf curling, leaf distortion, leaf tip death, stunted growth, and shoot meristem death. Only 4 plants of 17 flowered and many died in early growth stages even when soil $\mathrm{Ca}$ level was abundant and $\mathrm{Ca}$ fertilizer was given.

\section{Discussion}

At any point in time, the mineral content of a plant organ must be due to a combination of a) the quantity of mineral reserves previously stored, and b) movement of the mineral into or out of the organ during growth, and c) losses caused by physical factors such as abscission or foliar leaching (which we assert can be ignored in these experiments since the plants were grown in a greenhouse, and not subjected to overhead precipitation or irrigation).

In the first month after planting, 'Star Gazer' lily plants had negative net growth as bulb reserves were consumed before the development of a photosynthetically competent canopy (Fig. 1A; Table 1). In this period, the stem-root system was developing, but only weighed $0.4 \mathrm{~g}$ dry weight by $30 \mathrm{DAP}$ (Table 1; Fig. 1E). Whole plant calcium content increased from $8.9 \mathrm{mg}$ (in the planted bulb) to $20.8 \mathrm{mg} 30 \mathrm{DAP}$ (Table 1). While this is a doubling of calcium content, it is only a small increase compared to later stages of growth (Fig. 1A), and reflects the lack of a vigorous stem-root system (Fig. 1E). ULN occurred mainly from 30 to 40 DAP (Chang, 2002); this was the stage the shoot was in a rapid growth phase (Fig. 1C and D; Table 1) and the scales were rapidly depleting (Fig. 1B; Table 1). It is well-known in other crops that rapid growth increases Ca demand (Collier and Tibbitts, 1982; Kirkby and Pilbeam, 1984; Thibodeau and Minotti, 1969). In lettuce, the inner leaves which developed calcium deficiency (expressed as the disorder, tipburn), most frequently had higher relative growth rates than other inner leaves (Collier and Huntington, 1983). After 50 DAP, 'Star Gazer' lily was free from further development of ULN. At this stage, substantial stem-root growth had occurred (Fig. 1E), and leaf growth rate was not as rapid as in the susceptible period (Fig. 1C). This relationship between leaf and root growth also gives one explanation why the top leaves (such as leaves associated with the $4^{\text {th }}$ flower bud and above) were less affected by ULN (Chang, 2002). In addition, upper leaves of those plants grown from low-Ca bulbs were less susceptible to ULN compared to that grown from normal-Ca bulbs (Fig. 3). We suspect it is also related to growth rate. Plants grown from low-Ca bulbs grew slowly; during the time interval when upper leaves were supposed to be susceptible, an adequate stem-root system had been developed.

Throughout growth, leafCa concentration was much higher than in other organs. For example, at $70 \mathrm{DAP}$, leaves had $2.8 \% \mathrm{Ca}$, while Ca concentrations were only $0.47 \%, 0.19 \%, 0.21 \%$, and $0.19 \%$ in flowers, stem, stem roots, and bulb scales, respectively (Fig. 1B-F). At this stage, the plant had partitioned $23.8 \%$ of its dry matter to leaves, but the leaves contained $75.1 \%$ of whole plant Ca (Table 1 ). Similar high $\mathrm{Ca}$ accumulation in leaves has been reported in other lilies (Kawagishi and Miura, 1996; Roberts et al., 1964; Treder et al., 2001). In general, high Ca concentration is found in the foliage of plants (Hanson, 1983) and underground organs have less Ca (Demarty et al., 1984). In poinsettia, roots have significantly lower Ca concentration than shoots (Jacques et al., 1990). Mature leaves in cucumber are the strongest sinks for $\mathrm{Ca}$. The accumulation of $\mathrm{Ca}$ by the leaves accounts for $70 \%$ of the total $\mathrm{Ca}$ in aboveground parts of cucumber (Ho and Adams, 1994b).

Due to the fact that Ca is mainly transported by the transpiration stream, it accumulates in leaves (Hanson, 1983). When Ca supply is sufficient, plants partition more $\mathrm{Ca}$ to leaves; when $\mathrm{Ca}$ supply is limited, the proportion going to leaves is reduced. In the sand culture experiment, leaves contained $79 \%, 61 \%$, and $32 \%$ of the whole plant calcium content (mg basis) in the 4.0, 0.2, and 0.0 mм Ca treatments, respectively (based on Table 3). There was an 85-fold difference of leaf $\mathrm{Ca}$ concentration between the 4.0 $\mathrm{mm}$ and $0.0 \mathrm{~mm} \mathrm{Ca}$ treatments in the sand culture experiment, indicating that leaf $\mathrm{Ca}$ is very plastic depending on Ca availability to the roots (Table 3 ).

From 30 DAP to 40 DAP, the period most plants began to show ULN symptoms, dry matter of leaves doubled, from 1.3 $\mathrm{g}$ to $2.6 \mathrm{~g}$. However, leaf $\mathrm{Ca}$ content increased from $1.7 \mathrm{mg}$ to $22.7 \mathrm{mg}$, a 13-fold increase (Table 1). Leaves seemed to have an extremely high $\mathrm{Ca}$ demand after $30 \mathrm{DAP}$, so that both $\mathrm{Ca}$ concentration and Ca content increased dramatically (Fig. 1B; Table 1). At 40 DAP, leaves had only $17.2 \%$ of dry matter, but had $48.4 \%$ of the Ca (Table 1 ).

Before 30 DAP, bulb scales were the dominant organ for calcium within the plant. However, after 40 DAP, leaves became the most dominant (Table 1). At the most susceptible stage for ULN, which was $\approx 25$ to 40 DAP, Ca content in bulb scales was largely decreased and stem roots were not yet well-developed; the Ca supply was not able to meet the demand of leaves. Calcium concentration of the young (folded) leaves decreased dramatically from $0.33 \%$ on 0 DAP to $0.05 \%$ on 30 DAP, and was $<0.11 \%$ during 20 to 40 DAP (Fig. 2D). Consequently, necrosis began to show on these leaves. It has been suggested that the reduction of $\mathrm{Ca}$ concentration caused by high growth rate might increase the susceptibility of the tissue to Ca deficiency (Bangerth, 1979), and the current data clearly show this to be the case.

From 0 DAP to 40 DAP, Ca concentration in bulb scales increased with time (Fig. 1B). During this period, the basal roots were degenerating (Table 1) and the stem-root system was not well-developed, especially in the first $30 \mathrm{~d}$. We compared the raw data of each individual plant and found that there was no correlation between basal-root dry weight and bulb scale Ca concentration. We have also found that ULN and plant growth were not affected if basal roots were removed at planting (Chang and Miller, unpublished data). This suggests that bulb scales may have a special mechanism to absorb Ca directly from soil. It is generally recognized that leaves are able to absorb mineral nutrients (Marschner, 1995). Botanically, lily scales are modified leaves and have stomata (De Hertogh and Le Nard, 1993; Chang and Miller, unpublished data). Therefore, scales may be able to take up $\mathrm{Ca}$ through stomatal openings or physical wounds. Another possibility is by diffusion, since Ca concentration in the soil mix was $\approx 1 \%$ (Chang, 2002), but only $0.04 \%$ in bulb scales. Similar findings have indicated (Krauss and Marschner, 1971) that potato tubers could take up larger quantities of Ca directly from the soil solution. It was shown ${ }^{45} \mathrm{Ca}$ penetrated from the tuber surface into deeper layers of the growing tubers.

Both dry matter and $\mathrm{Ca}$ content of flower buds increased dramatically after 50 DAP (Fig. 1F). At this stage of high flower bud demand for $\mathrm{Ca}$, the stem-root system was well-established (Fig. 1E) and the shoot apex was not enclosed by leaves. This could partially explain why flower buds were much less susceptible compared to leaves. 
Critical tissue $\mathrm{Ca}$ concentrations leading to deficiency vary widely. Calcium requirements vary between species, and Loneragan and Snowball (1969) suggested that conditions of supply could be a major source of variation in the diagnostic values reported in the literature. Other sources of variation may come from sampling and analytic methods (Barta and Tibbitts, 2000). Our previous study indicated that the critical $\mathrm{Ca}$ concentration associated with ULN for leaf tissue was about 0.3 to $0.4 \%$ (Chang, 2002). Most of the time, $\mathrm{Ca}$ concentration of all organs, except leaves, was less than this level (Fig. 1B-F). It is clear that different organs have different $\mathrm{Ca}$ requirements that vary with growth stage. Leaf L13 had Ca concentration as low as $0.04 \%$ on 20 DAP, yet it was not necrosed (Fig. 2A). Therefore, we propose that the occurrence of ULN does not depend on absolute Ca concentration, rather it depends on the Ca demand at a certain growth stage (growth rate), and whether the supply is sufficient or not. Thus, it is difficult to define the absolute threshold of Ca concentration likely to lead to Ca deficiency symptoms. Similarly Wissemeier (1993) reported that sometimes poinsettia did not show marginal bract necrosis even with $\mathrm{Ca}$ concentrations as low as $0.15 \%$.

Necrosis symptoms only appeared on the upper leaves, even on plants provided with $\mathrm{Ca}$-free nutrient solution. This indicates that bulb calcium reserves and calcium previously stored in the stem and leaf primordia were sufficient for growth and development of the lower and middle leaves in the absence of external calcium. At planting, whole bulbs in the sand culture experiment had 6.0 $\mathrm{mg} \mathrm{Ca}$. After $88 \mathrm{~d}$, the total $\mathrm{Ca}$ content of the whole plant in the $0.0 \mathrm{~mm} \mathrm{Ca}$ treatment was $5.0 \mathrm{mg}$ (Table 3), the loss of $1.0 \mathrm{mg}$ being due to Ca loss from degenerated bulb scales, leaf abscission and aborted flower buds. This indicated that without Ca supply from either soil or nutrient solution, some $\mathrm{Ca}$ was translocated from the scales into other organs. The bulbs used in the sand culture experiment were smaller ( $12.9 \mathrm{~g}$ dry weight, Table 3 ) than in the sequential harvest experiment $(18.2 \mathrm{~g}$ dry weight, Table 1). By calculations based on Table 1, the initial $\mathrm{Ca}$ content in leaf primordia at planting should be around $0.35 \mathrm{mg}$ in the sand culture experiment. After 88 d growth in the absence of $\mathrm{Ca}, \mathrm{Ca}$ content in the leaves increased to $1.6 \mathrm{mg}$. It was also found that potato tubers were able to translocate $\mathrm{Ca}$ to the sprouts when no nutrient solution was supplied (Wallace et al., 1980). Dividing the sprouts into three sections, the upper third had the lowest $\mathrm{Ca}$ concentration. As a consequence, the sprout tip necrosed. These results are very similar to our findings. However, there is a lack of information on how $\mathrm{Ca}$ is translocated from storage organs to leaves. In general, under abundant soil $\mathrm{Ca}$ conditions, bulb Ca concentration increased over time after planting (Fig. 1B). However, in the 0.2 and $0.0 \mathrm{~mm}$ Ca treatments in the sand culture experiment, $\mathrm{Ca}$ concentration in bulbs dropped from $0.05 \%$ to $0.02 \%$ and $0.01 \%$, respectively. This provided more evidence that the bulb scales supply some Ca to other organs.

In summary, $\mathrm{Ca}$ supply to the lower and middle leaves was highly dependent on translocation from the bulb in the first month. Therefore, in our low-Ca bulb experiment, even with sufficient $\mathrm{Ca}$ in the soil and nutrient solution, necrosis symptoms were seen on the lower and middle leaves. After 30 DAP, when stem roots were better developed and scales were largely depleted, Ca supply from soil became important to upper leaves. Although it is generally agreed that $\mathrm{Ca}$ is phloem immobile and thus not translocated between organs (Kirkby and Pilbeam, 1984; Loneragan and Snowball, 1969; Marschner, 1995), it may not apply to species with a storage organ.

'Star Gazer' lilies grown from smaller bulbs such as 14 to 16 $\mathrm{cm}$ are not normally susceptible to ULN when grown under regular Ca fertility (Chang and Miller, unpublished data). However, by using a Ca-free nutrient solution in sand cultures with smaller bulbs, we were able to induce ULN symptoms, confirming that ULN is a Ca deficiency disorder. We concluded ULN is primarily caused by insufficient $\mathrm{Ca}$ supply from the bulb. Calcium reserves in bulbs were only able to supply early growth needs of the lower and middle leaves, but not those of the later stages. This may explain why ULN is only exhibited on upper leaves of Lilium 'Star Gazer'.

\section{Literature Cited}

Adams, P. and L.C. Ho. 1992. The susceptibility of modern tomato cultivars to blossom-end rot in relation to salinity. J. Hort. Sci. 67: 827-839.

Adams, P. and L.C. Ho. 1993. Effects of environment on the uptake and distribution of calcium in tomato and on the incidence of blossom-end rot. Plant Soil 154:127-132.

Bangerth, F. 1979. Calcium-related physiological disorders of plants. Annu. Rev. Phytopathol. 17:97-122.

Barta, D.J. and T.W. Tibbitts. 1986. Effects of artificial enclosure of young lettuce leaves on tipburn incidence and leaf calcium concentration. J. Amer. Soc. Hort. Sci. 111:413-416.

Barta, D.J. and T.W. Tibbitts. 2000. Calcium localization and tipburn development in lettuce leaves during early enlargement. J. Amer. Soc. Hort. Sci. 125:294-298.

Bradfield, E.G. and C.G. Guttridge. 1979. The dependence of calcium transport and leaf tipburn in strawberry on relative humidity and nutrient solution concentration. Ann. Bot. 43:363-372.

Bunemann, G. and A. Grassia. 1973. Growth and mineral distribution in grafted tomato/potato plants according to sink number. Sci. Hort. $1: 13-24$

Chang, Y.C. 2002. Upper leaf necrosis on Lilium cv. Star Gazer-A calcium deficiency disorder. PhD diss. Cornell Univ., Ithaca, N.Y. Diss. Abstr. Intl. 63-09B: 4077.

Chaplin, M.H. and A.N. Roberts. 1981. Seasonal nutrient element distribution in leaves of 'Ace' and 'Nellie White' cultivars of the Easter lily, Lilium longiflorum L. Commun. Soil Sci. Plant Anal. 12:227-237.

Collier, G.F. and V.C. Huntington. 1983. The relationship between leaf growth, calcium accumulation and distribution, and tipburn development in field-grown butterhead lettuce. Sci. Hort. 21:123-128.

Collier, G.F. and T.W. Tibbitts. 1982. Tipburn of lettuce. Hort. Rev. 4: 49-65.

Collier, G.F., D.C.E. Wurr, and V.C. Huntington. 1978. The effect of calcium nutrition on the incidence of internal rust spot in the potato. J. Agric. Sci. 91:241-243.

De Hertogh, A.A. and M. Le Nard. 1993. Botanical aspects of flower bulbs, p. 7-20. In: A.A. De Hertogh and M. Le Nard (eds.). The physiology of flower bulbs. Elsevier Science Publishers B.V., Amsterdam, The Netherlands.

Demarty, M., C. Morvan, and M. Thellier. 1984. Calcium and the cell wall. Plant Cell Environ. 7:441-448.

Ferguson, I.B. and C.B. Watkins. 1989. Bitter pit in apple fruit. Hort. Rev. 11:289-355.

Guttridge, C.G., E.G. Bradfield, and R. Holder. 1981. Dependence of calcium transport into strawberry leaves on positive pressure in the xylem. Ann. Bot. 48:473-480.

Hanson, J.B. 1983. The roles of calcium in plant growth. Curr. Top. Plant Biochem. Physiol. 1:1-24.

Ho, L.C. and P. Adams. 1994a. The physiological basis for high fruit yield and susceptibility to calcium deficiency in tomato and cucumber. J. Hort. Sci. 69:367-376.

Ho, L.C. and P. Adams. 1994b. Regulation of the partitioning of dry matter and calcium in cucumber in relation to fruit growth and salinity. Ann. Bot. 73:539-545.

Ho, L.C., R. Belda, M. Brown, J. Andrews, and P. Adams. 1993. Uptake 
and transport of calcium and the possible causes of blossom-end rot in tomato. J. Expt. Bot. 44:509-518.

Jacques, D.J., R.E.J. Boerner, and J.C. Peterson. 1990. Effects of Ca supply and stress on uptake and translocation of $\mathrm{Ca}$ in two poinsettia cultivars. Environ. Expt. Bot. 30:525-531.

Johnson, C.M.,P.R. Stout, T.C. Broyer, andA.B.Carlton. 1957. Comparative chlorine requirements of different plant species. Plant Soil 8:337-353.

Kawagishi, K. and T. Miura. 1996. Changes in nutrient content of springplanted edible lily (Lilium leichtlinii Hook f. var. maximowiczii Baker). J. Jpn. Soc. Hort. Sci. 65:339-347.

Kirkby, E.A. and D.J. Pilbeam. 1984. Calcium as a plant nutrient. Plant Cell Environ. 7:397-405.

Krauss, A. and H. Marschner. 1971. Influence of direct calcium supply to potato tubers on tuber yield and calcium content. Zeitschrift fur Pflanzenernahrung und Bodenkunde 129:1-9.

Loneragan, J.F. and K. Snowball. 1969. Calcium requirements of plants. Austral. J. Agr. Res. 20:465-478.

Marschner, H. 1995. Mineral nutrition of higher plants. Academic Press, London, U.K.

Miller, W.B. 1992. Easter and hybrid lily production-Principles and practice. Timber Press, Portland, Ore.

Olsen, N.L., L.K. Hiller, and L.J. Mikitzel. 1996. The dependence of internal brown spot development upon calcium fertility in potato tubers. Potato Res. 39:165-178.

Palzkill, D.A. and T.W. Tibbitts. 1977. Evidence that root pressure flow is required for calcium transport to head leaves of cabbage. Plant Physiol. 60:854-856.

Roberts, A.N., L.T. Blaney, and O.C. Compton. 1964. Seasonal changes of certain nutrient elements in the leaves and bulbs of Croft lily, Lilium longiflorum and their relation to bulb yield. Proc. Amer. Soc. Hort. Sci. 85:611-630.

Shear, C.B. 1975. Calcium-related disorders of fruits and vegetables. HortScience 10:361-365.

Thibodeau, P.O. and P.L. Minotti. 1969. The influence of calcium on the development of lettuce tipburn. J. Amer. Soc. Hort. Sci. 94:372-376.

Treder, J., E. Maloupa, and D. Gerasopoulos. 2001. The effect of light and nutrition on growth and flowering of oriental lilies. Acta Hort. 548:523-528.

Wallace, A., S.M. Soufi, E.M. Romney, and G.V. Alexander. 1980. Translocation of calcium and other nutrients from potato tubers to sprouts. J. Plant Nutr. 2:237-243.

Wissemeier, A.H. 1993. Marginal bract necrosis in poinsettia cultivars and the relationship to bract calcium nutrition. Gartenbauwissenschaft 58:158-163. 